\title{
Chemical Composition and In Vitro Antiplasmodial Activity of the Ethanolic Extract of Cyperus articulatus var. nodosus Residue
}

\author{
Francisco Flávio Vieira de Assis ${ }^{1}{ }^{\mathbb{B}}$, Nazaré Carneiro da Silva ${ }^{2}$, Waldiney Pires Moraes ${ }^{2}$, \\ Lauro Euclides Soares Barata ${ }^{3}\left[\right.$ and Antonio Humberto Hamad Minervino ${ }^{1, *}$ (i) \\ 1 Laboratory of Animal Health, LARSANA, Federal University of Western Pará, UFOPA, \\ Santarém, Pará 68040-255, Brazil; flavioassis131995@hotmail.com \\ 2 Pharmacology Laboratory, Federal University of Western Pará, Santarém, Pará 68040-255, Brazil; \\ nazaresilvaufopa@hotmail.com (N.C.d.S.); waldineypires@gmail.com (W.P.M.) \\ 3 Laboratory for Research \& Development of Bioactive Products, Federal University of Western Pará, \\ Santarém, Pará 68040-255, Brazil; lauroesbarata@gmail.com \\ * Correspondence: ah.minervino@gmail.com
}

Received: 10 October 2020; Accepted: 24 October 2020; Published: 27 October 2020

\begin{abstract}
Cyperus articulatus L. is popularly known as priprioca. Its rhizomes are used as a medicine in the treatment of malaria in traditional medicine. Since priprioca oil is extracted for commercial purpose, we evaluated if the components from the priprioca residue can be a source of antiplasmodial active molecules. This study aimed to determine the in vitro antiplasmodial and cytotoxicity activities of the ethanolic extract of $C$. articulatus as an in vitro antiplasmodial agent. From the solid residue of the plant rhizomes, $40 \mathrm{~g}$ samples were removed and subjected to hot extraction using a Soxhlet extractor. The in vitro antiplasmodial activity was determined using the W2 and 3D7 strains of P. falciparum. The phytochemical study identified the following main compounds: corymbolone $(14.25 \%)$, cyclocolorenone $(9.75 \%)$, and cadalene $(8.36 \%)$. The extract exhibited moderate $\mathrm{IC}_{50}$ (inhibitory concentration) against the two strains of $P$. falciparum: $1.21 \pm 0.01$ against the W2 strain and $1.10 \pm 0.06 \mu \mathrm{g} / \mathrm{mL}$ against the 3D7 strain. Our results show the therapeutic potential of priprioca residue as a low-cost antiplasmodial agent.
\end{abstract}

Keywords: malaria; priprioca; phytotherapic; antimalarial

\section{Introduction}

Malaria is an infectious, parasitic disease that affects millions of people in the tropical and subtropical regions worldwide, mainly in Africa, Southeast Asia, and the Amazon region of South America [1-3]. According to the World Health Organization [4], there were 228 million cases of malaria worldwide in 2018 with 405,000 deaths. Malaria is considered the most important potentially fatal parasitic disease of human beings [5].

In Brazil, most cases are in the Amazon region, owing to, among other factors, the favorable conditions for the existence of the vector, the lack of adequate sanitation, potential risk of zoonotic transmission from nonhuman primates, and disorderly settlements near too forested areas, causing serious problems in public health and great economic impact affecting millions of people [6-8].

Malaria, a disease caused by protozoa belonging to Plasmodium, has a large impact on the world, putting at risk approximately $40 \%$ of the world population (about 2.4 billion people) in more than 100 countries [9]. This disease is transmitted to humans by infected female Anopheles mosquitoes. $P$. falciparum is the most dangerous species of the genus because it can lead to the most severe form of 
malaria, cerebral malaria, which without treatment is invariably fatal and in patients treated adequately the mortality rate is around $15-20 \%[10,11]$.

The resistance of $P$. falciparum to artemisinin derivatives in Southeast Asia threatens malaria control $[12,13]$. High prevalence of $P$. vivax genotypes associated with chloroquine resistance highlights the severe situation of Malaria treatment in Oceania and South Asian regions [14]. The search for new drugs for treatment is steadily increasing because of the parasite's resistance to traditional therapy [15].

The importance of natural products, including those derived from plants, is recognized in the development of therapeutic drugs for different purposes in animals [16] and humans. Approximately $40 \%$ of the drugs currently available have been developed directly or indirectly from natural sources, of which $25 \%$ are from plants $[17,18]$. There is a great diversity of plant species worldwide and in the Brazilian Amazon, with the potential for investigation of new secondary metabolites with antiplasmodial action $[6,19]$. Cyperus articulatus L. belongs to the Cyperaceae family and is popularly known as priprioca in Brazil, mainly in the Amazon region, where it is traditionally used as a sedative, anticonvulsant, and anti-inflammatory agent [20]. Its rhizomes are used as a source of herbal medicines for fever and seizures and in the treatment of malaria in traditional medicine [21]. There has been a growing interest in studies of $C$. articulatus in recent years owing to the pleasant aroma of the volatile oil obtained from the rhizome of the plant for perfumery industry [20] and its medicinal effects.

When essential oil is removed from priprioca rhizome, organic solid waste is generated which still contains significant amounts of metabolites with medicinal activity. In this context, the objective of the present study was to assess the effect of the ethanolic extract of $C$. articulatus rhizome residue as an in vitro antiplasmodial agent.

\section{Material and Methods}

\subsection{Collection and Identification of Plant Materials}

Rhizomes of the species Cyperus articulatus var. nodosus, popularly known as priprioca, were collected in August 2014, in the Tabocal region of the municipality of Santarém, Pará, Brazil $\left(-54^{\circ} 43^{\prime} 00.10^{\prime \prime} \mathrm{W}-02^{\circ} 37^{\prime} 41.10^{\prime \prime} \mathrm{S}\right)$. The species was identified by the botanist Dr. Antônio Elielson Sousa da Rocha, from the Museu Paraense Emilio Goeldi, where a specimen is deposited (MG-207174). The plant's name was verified on the online website (www.theplantlist.org) of the Royal Botanic Gardens, Kew, accessed on July 7, 2020.

\subsection{Preparation of the Ethanolic Extract of C. articulatus (EECA)}

Five kilograms of the rhizomes of $C$. articulatus were collected. After collection, the rhizomes were cleaned, dried for three consecutive days, and ground in a knife mill in an open environment. After drying, the crushed material was subjected to hydrodistillation by a $150 \mathrm{~L}$ steam distillation system for 1.5 to $4 \mathrm{~h}$, to obtain the essential oil. From the solid vegetable residue waste originating from the extraction by steam system, $40 \mathrm{~g}$ samples were removed and subjected to hot extraction in a Soxhlet extractor using ethanol $96 \%$. The solvent of the solution resulting from the hot extraction was evaporated in a rotary evaporator under reduced pressure to obtain a concentrate of the ethanolic extract of the residue of $C$. articulatus.

\subsection{Chromatographic Analysis of the EECA}

The analysis of the chemical composition of the EECA was performed in an Agilent gas chromatograph, model HP-6890 equipped with a selective Agilent mass detector, model HP-5975 using an HP-5MS capillary column $(30 \mathrm{~m} \times 0.25 \mathrm{~mm} \times 0.25 \mu \mathrm{m})$ under the following conditions: injector temperature $=250^{\circ} \mathrm{C}$, column $=80^{\circ} \mathrm{C}$, heating rate $=5^{\circ} \mathrm{C} / \mathrm{min}$ to $280^{\circ} \mathrm{C}(20 \mathrm{~min})$, and detector $=300^{\circ} \mathrm{C}$. Helium was used as carrier gas at a flow rate of $1 \mathrm{~mL} / \mathrm{min}$ and a selective mass detector operating at $70 \mathrm{eV}, \mathrm{m} / \mathrm{z}=30$ to 500 u.m.a. The EECA was solubilized in ethyl acetate at a concentration of $20 \mathrm{mg} / \mathrm{mL}$ 
and the identification of the major compounds in the extract was performed by comparison with the electronic library of the equipment (NIST-11).

\subsection{Assessment of Cell Viability}

For the analysis of cell viability, 3-(4,5-dimethylthiazol-2-yl)-2,5-diphenyltetrazolium bromide (MTT, Sigma-Aldrich, Inc. St. Louis, MO, USA) was used with the cell line WI-26VA-4 (lung fibroblast ATCC CCL-95.1); this strain is part of the animal cell bank of the Cell Biology Service (SBC) of the Ezequiel Dias Foundation (FUNED). The cells were maintained in RPMI1640 medium supplemented with $21 \mathrm{mM}$ bicarbonate, $40 \mathrm{mg} / \mathrm{mL}$ gentamicin, and 10\% $(v / v)$ inactivated fetal bovine serum. A cell suspension was distributed in a 96-well plate at a concentration of $1 \times 10^{5}$ cells/well, and incubated for $24 \mathrm{~h}$ at $37{ }^{\circ} \mathrm{C}$ in a humid atmosphere containing $5 \% \mathrm{CO}_{2}$. After that, the cells were washed with phosphate-buffered saline. Subsequently, the EECA was added at different concentrations, ranging from 1000 to $0.1 \mu \mathrm{g} / \mathrm{mL}$. After $48 \mathrm{~h}$ of incubation, the plate was washed again with phosphate-buffered saline with $100 \mu \mathrm{L}$ of MTT tetrazolium salt added at a concentration of $5 \mathrm{mg} / \mathrm{mL}$. The plate was incubated again for another $3 \mathrm{~h}$. After discarding the supernatant, $50 \mu \mathrm{L}$ of dimethyl sulfoxide (DMSO, Sigma-Aldrich, Inc. St. Louis, MO, USA)) was added, and the color obtained was evaluated by reading on a microplate spectrophotometer (model Espectramax M5e, Molecular Devices LLC, San Jose, CA, USA) at a wavelength of $550 \mathrm{~nm}$. The concentration that inhibited cell growth by $50 \%\left(\mathrm{LC}_{50}\right)$ was determined in comparison to cells cultured without the test compound.

\subsection{Evaluation of Hemolytic Activity}

Fresh blood $(5 \mathrm{~mL})$ was collected in an EDTA tube and centrifuged at $1000 \times g$ for 5 min at $4{ }^{\circ} \mathrm{C}$. The supernatant was removed, and the pellet with red blood cells was washed five times with saline solution ( $0.9 \%$ sterile) and then suspended in the same solution to obtain a $1 \%(v / v)$ red cell solution. The test compound was diluted in a 1\% DMSO solution and tested in triplicate at concentrations of 1000 to $15.6 \mu \mathrm{g} / \mathrm{mL}$ in seven serial dilutions (1:2), and $100 \mu \mathrm{L}$ of the $1 \%$ red blood cell suspension was added $(v / v)$ in each well. The resulting suspensions were incubated for $60 \mathrm{~min}$ at $37^{\circ} \mathrm{C}$. After incubation, the samples were centrifuged for $2 \mathrm{~min}$ at $1000 \times \mathrm{g}$. The supernatants were transferred to 96-well plates and the release of hemoglobin was measured by absorbance at $450 \mathrm{~nm}$ (Abs450nm) using a BioTek Synergy HT multiplate reader. To control 100\% hemolysis, red blood cells were suspended in $1 \%$ $(v / v)$ Triton X-100. As a control without hemolysis, a $0.9 \%$ saline solution was used. The percentage of hemolysis was determined using the following equation: [(Abs450nm treated sample-Abs450nm untreated $) /($ Abs450nm1\% Triton X-100-Abs450nm untreated)] $\times 100$ [22].

\subsection{Evaluation of In Vitro Antiplasmodial Activity}

In vitro antiplasmodial activity was determined using W2 (chloroquine-resistant) and 3D7 (chloroquine-sensitive) strains of Plasmodium falciparum grown in human A+ red blood cells in a predominantly ring stage, synchronized using the sorbitol method [23]. RPMI 1640 culture medium supplemented with $25 \mathrm{mM}$ HEPES, $21 \mathrm{mM}$ sodium bicarbonate, $300 \mathrm{mM}$ hypoxanthine, $11 \mathrm{mM}$ glucose, $40 \mathrm{mg} / \mathrm{mL}$ gentamicin, and 10\% (v/v) inactivated human plasma was used. The cultures synchronized with $2 \%$ parasitemia and $2 \%$ hematocrit were distributed in a 96-well microplate. The EECA was added at a starting concentration of $50 \mu \mathrm{g} / \mathrm{mL}$ and twofold serial diluted in incomplete culture medium and $4 \%$ DMSO until the final concentration of $0.049 \mu \mathrm{g} / \mathrm{mL}$. We tested the following concentrations of ECA: 50, 25, 12.5, 6.25, 3.125, 1.56, 0.78, 0.39, 0.195, 0.098, 0.049 $\mu \mathrm{g} / \mathrm{mL}$. Chloroquine was used as a standard antimalarial. The plate was incubated for $48 \mathrm{~h}$ at $37{ }^{\circ} \mathrm{C}$ with $5 \% \mathrm{CO}_{2}$ and $95 \%$ relative humidity. Smears corresponding to each well were made. After being fixed with methanol and stained with Giemsa, the smears were used to count the parasitemia under an optical microscope (1000×). The activity of the compounds was expressed as the percentage of reduction in parasitemia in relation to the negative control (without any antiplasmodial drug), which was considered as $100 \%$ of the growth of the parasite. The experiment was performed in triplicate with each concentration of EECA extract, 
positive and negative controls, tested three times, totaling 39 independent assays per strain (total of 78). The slide reading was blinded (i.e., the slides had codes, and the observer did not know the treatment used in each slide) and performed by the same trained researcher. The concentration of extract that inhibited $50 \%$ of the growth of the parasite $\left(\mathrm{IC}_{50}\right)$ was determined through dose-response curves, as a function of nonlinear regression.

\subsection{Selectivity Index}

The selectivity index (SI) is the relationship between the cytotoxic and antiparasitic activities of each compound. The SI was obtained from the ratio between the $\mathrm{LC}_{50}$ value for WI cell line and the $\mathrm{IC}_{50}$ for $P$. falciparum (strain W2) according to the formula: $\mathrm{SI}=\mathrm{LC}_{50}$ cell line WI/IC 50 P. falciparum (strain W2). Values greater than 10 were considered indicative of high selectivity, whereas substances with values below 10 were considered to have low selectivity [24].

\subsection{Statistical Analysis}

Statistical analyses were performed using OriginPro 8.0 (OriginLab Corporation, Northampton, MA, USA) to determine the $\mathrm{IC}_{50}$ value of the in vitro test.

\section{Results}

The phytochemical study of the ethanolic extract of C. articulatus obtained from residues derived from the extraction of essential oil resulted in the identification of the following main compounds: alpha-bulnesene, cadalene, cyperotundone, cis-thujopsenal, cyclocolorenone, corymbolone, hexadecanoic acid ethyl ester, 9,12-octadecanoic acid ethyl ester, 9-octadecenoic acid ethyl ester, and cholesta-3,5-diene. Together, these compounds represented more than $60 \%$ of the total sample (Table 1).

Table 1. Chemical composition of the ethanolic extract of the Cyperus articulatus residue.

\begin{tabular}{ccc}
\hline Identification & $\left.\mathbf{t}_{\mathbf{R}} \mathbf{( m i n}\right)$ & $\mathbf{R e l} \%$ \\
\hline alpha-bulnesene & 15.01 & 1.18 \\
\hline cadalene & 18.95 & 8.36 \\
\hline cyperotundone & 19.34 & 2.88 \\
\hline cis-thujopsenal & 19.59 & 4.19 \\
\hline cyclocolorenone & 20.49 & 9.75 \\
\hline corymbolone & 23.32 & 14.25 \\
\hline 9,12-octadecadienic acid ethyl ester & 28.27 & 3.24 \\
\hline 9-octadecenoic acid ethyl ester & 28.38 & 5.5 \\
\hline cholesta-3,5-diene & 39.63 & 4.82 \\
\hline Total identified: & & 60.16 \\
\hline
\end{tabular}

$t_{\mathrm{R}}$ : retention time; Rel\%: relative percentage.

The compound identification shows the presence of mainly sesquiterpenes, wherein the highest yield $(14.25 \%)$ was obtained for corymbolone. The EECA at the tested concentrations did not show hemolysis, similar to the control with $0.9 \%$ saline.

In the in vitro antiplasmodial test, the EECA presented an $\mathrm{IC}_{50}$ value of $1.21 \pm 0.01$ obtained from dose-response curves for the culture of $P$. falciparum against the W2 strain (chloroquine-resistant) and an $\mathrm{IC}_{50}$ value of $1.10 \pm 0.06$ against the 3D7 strain (chloroquine-sensitive) (Table 2). In the cytotoxicity test with the WI cell line, using the MTT colorimetric method, the EECA showed an LC $_{50}$ value of 
$>$ 100. In calculating the SI based on the ratio between the toxic dose and its antimalarial activity, P. falciparum demonstrated that the EECA is a safe compound with SI values $>91$ for the 3D7 strain and 83 for the strain W2 (Table 2).

Table 2. In vitro antiplasmodial activity, cytotoxicity (human lung fibroblast, Wi 26VA-4), and selectivity index (SI) of ethanolic extract of Cyperus articulatus rhizomes against Plasmodium falciparum strains W2 and 3D7, and using chloroquine as control.

\begin{tabular}{ccccccc}
\hline Compound & \multicolumn{2}{c}{$\mathrm{IC}_{\mathbf{5 0}}(\mu \mathrm{g} / \mathrm{mL}) \pm \mathrm{SD}^{*}$} & Antiplasmodial Activity & LC $_{\mathbf{5 0}}(\boldsymbol{\mu g})$ & \multicolumn{2}{c}{ SI } \\
\hline & 3D7 & W2 & & & 3D7 & W2 \\
\hline Ethanolic Extract & $1.10 \pm 0.06$ & $1.21 \pm 0.01$ & Active & $>100$ & $>91$ & 83 \\
\hline Chloroquine & $0.46 \pm 0.08$ & $0.21 \pm 0.01$ & Active & $>100$ & $>200$ & $>200$ \\
\hline
\end{tabular}

$\mathrm{IC}_{50}$ : average inhibitory concentration; $\mathrm{LC}_{50}$ : mean lethal concentration. ${ }^{*}$ Values are expressed by mean $\pm \mathrm{SD}$ (standard deviation).

\section{Discussion}

Preliminary studies evaluating the extract of $C$. articulatus also identified elevated concentration of corymbolone among all the other identified substances and showed in vitro antiplasmodial activity [25]. Considering the verified antiplasmodial action and the low toxicity of this molecule, it may has potential to be used as an alternative of chloroquine, which has adverse effects [26,27]. Alpha-bulnesene has biological activity related to the inhibition of platelet activation factor [28]. Toxicity analysis, which is necessary when investigating the biological activity of products with potential for phytotherapy, is conducted with the objective of determining the potential of new substances and products without causing risk to human health and classifying them according to their potential for lethality or toxicity as established by legislation [29].

Research using ethanol extract from leaves of Montrichardia linifera (Arruda) Schott showed moderate antiplasmodial activity $\left(10<\mathrm{IC}_{50}<100 \mu \mathrm{g} / \mathrm{mL}\right)$ [30], which is below that found in this study $\left(\mathrm{IC}_{50}=1.21 \mu \mathrm{g} / \mathrm{mL}\right)$. However, work with Artemisia turcomanica extract obtained antiplasmodial activity with $\mathrm{IC}_{50}$ and IC90 values of $0.90 \pm 0.27 \mathrm{mg} / \mathrm{mL}$ and $1.62 \pm 0.68 \mathrm{mg} / \mathrm{mL}$, respectively [31].

As for cytotoxic activity, one study found that $C$. articulatus essential oil was moderately cytotoxic to monkey kidney cells [32]. However, with C. articulatus essential oil, a noncytotoxic result was obtained for human pulmonary fibroblasts by cell viability assay with MTT $\left(\mathrm{LC}_{50}>100 \mu \mathrm{g} / \mathrm{mL}\right)$ [32]. It was also observed that the $\mathrm{IC}_{50}$ of $\mathrm{W} 2$ and 3D7 strains of P. falciparum treated with essential oil were $1.21 \mu \mathrm{g} / \mathrm{mL}$ and $2.30 \mu \mathrm{g} / \mathrm{mL}$, respectively [33], consistent with the findings in this study.

In addition, an in silico study of the activities of triterpenes and iridoids isolated from Himatanthus articulatus (Vahl) Woodson did not identify any molecules with antiplasmodial activity [34]. One limitation of the present study is related to the source of antiplasmodial activity. We found three major components in the residue extract, corymbolone (14.25\%), cyclocolorenone $(9.75 \%)$, and cadalene $(8.36 \%)$. The antimalarial activity is most likely from one of those or from a combined effect between two or more compounds present in the tested extract. Further studies are required to verify the antiplasmodial activity using purified chemical components found in the ethanolic extract of priprioca residue, which could be used as a new drug for malaria treatment.

\section{Conclusions}

The ethanolic extract obtained from the rhizome residue of Cyperus articulatus from Santarém, Brazil, contained corymbolone as the main compound identified and exhibited a moderate level of activity against two strains of Plasmodium falciparum (W2 and 3D7). The EECA also showed low cytotoxicity against the human cell line WI-26-VA-4. Our results demonstrate the therapeutic potential of $C$. articulatus as an antiplasmodial agent. 
Author Contributions: Conceptualization: F.F.V.d.A., A.H.H.M., L.E.S.B., A.H.H.M.; Experiments: F.F.V.d.A., N.C.d.S., W.P.M.; Data analysis: W.P.M., L.E.S.B., A.H.H.M.; Chemical analysis: L.E.S.B.; Writing manuscript: F.F.V.d.A., N.C.d.S.; Revising manuscript: A.H.H.M., W.P.M., L.E.S.B. All authors have read and agreed to the published version of the manuscript.

Funding: This research received no external funding.

Acknowledgments: Antonio H. H. Minervino is a recipient of a research productivity fellowship from National Council for Scientific and Technological Development (CNPq), Brazil.

Conflicts of Interest: The authors declare no conflict of interest.

\section{References}

1. Laveran, A. Un nouveau parasite trouvé dans le sang de malades atteints de fièvre palustre. Origine parasitaire des accidents de l'impaludisme. Bull. Mém. Soc. Méd. Hôpitaux Paris 1881, 17, 158-164.

2. Ashley, E.A.; Pyae Phyo, A.; Woodrow, C.J. Malaria. Lancet 2018, 391, 1608-1621. [CrossRef]

3. Espinoza, J. Malaria Resurgence in the Americas: An Underestimated Threat. Pathogens 2019, 8, 11. [CrossRef] [PubMed]

4. World Health Organization. World Malaria Report 2019; World Health Organization: Geneva, Switzerland, 2019; ISBN 978-92-4-156572-1.

5. Dahmana, H.; Mediannikov, O. Mosquito-borne diseases emergence/resurgence and how to effectively control it biologically. Pathogens 2020, 9, 310. [CrossRef] [PubMed]

6. Meneguetti, D.U.O.; Cunha, R.M.d.; Lima, R.A.; Oliveira, F.A.S.; de Medeiros, D.S.; Passarini, G.M.; de Medeiros, P.S.D.M.; Militão, J.S.L.T.; Facundo, V.A. Antimalarial ethnopharmacology in the Brazilian Amazon. J. Basic Appl. Pharm. Sci. 2014, 35, 385-392.

7. Reiners, A.A.O.; de Azevedo, R.C.S.; Ricci, H.A.; de Souza, T.G. User adherence and reactions to malaria treatment: Implications for health education. Texto Context. Enferm. 2010, 19, 536-544. [CrossRef]

8. Monteiro, E.F.; Fernandez-Becerra, C.; da Araujo, M.S.; Messias, M.R.; Ozaki, L.S.; de Duarte, A.M.R.C.; Bueno, M.G.; Catao-Dias, J.L.; Chagas, C.R.F.; da Mathias, B.S.; et al. Naturally Acquired Humoral Immunity against Malaria Parasites in Non-Human Primates from the Brazilian Amazon, Cerrado and Atlantic Forest. Pathogens 2020, 9, 525. [CrossRef] [PubMed]

9. Gomes, A.P.; Vitorino, R.R.; de Costa, A.P.; de Mendonça, E.G.; de Oliveira, M.G.A.; Siqueira-Batista, R. Severe Plasmodium falciparum malaria. Rev. Bras. Ter. Intensiva 2011, 23, 358-369. [CrossRef] [PubMed]

10. França, T.C.C.; Dos Santos, M.G.; Figueroa-Villar, J.D. Malária: Aspectos históricos e quimioterapia. Quim. Nova 2008, 31, 1271-1278. [CrossRef]

11. Idro, R.; Marsh, K.; John, C.C.; Newton, C.R.J. Cerebral malaria: Mechanisms of brain injury and strategies for improved neurocognitive outcome. Pediatr. Res. 2010, 68, 267-274. [CrossRef] [PubMed]

12. Ariey, F.; Witkowski, B.; Amaratunga, C.; Beghain, J.; Langlois, A.C.; Khim, N.; Kim, S.; Duru, V.; Bouchier, C.; Ma, L.; et al. A molecular marker of artemisinin-resistant Plasmodium falciparum malaria. Nature 2014, 505, 50-55. [CrossRef] [PubMed]

13. Ashley, E.A.; Dhorda, M.; Fairhurst, R.M.; Amaratunga, C.; Lim, P.; Suon, S.; Sreng, S.; Anderson, J.M.; Mao, S.; Sam, B.; et al. Spread of artemisinin resistance in Plasmodium falciparum malaria. New Engl. J. Med. 2014, 371, 411-423. [CrossRef] [PubMed]

14. Noisang, C.; Meyer, W.; Sawangjaroen, N.; Ellis, J.; Lee, R. Molecular Detection of Antimalarial Drug Resistance in Plasmodium vivax from Returned Travellers to NSW, Australia during 2008-2018. Pathogens 2020, 9, 101. [CrossRef]

15. Wells, T.N.C.; van Huijsduijnen, R.H.; van Voorhis, W.C. Malaria medicines: A glass half full? Nat. Rev. Drug Discov. 2015, 14, 424-442. [CrossRef]

16. Américo, Á.V.L.d.S.; Nunes, K.M.; Assis, F.F.V.; Dias, S.R.; Passos, C.T.S.; Morini, A.C.; Araújo, J.A.; Castro, K.C.F.; Escher, S.K.S.; Barata, L.E.S.; et al. Efficacy of Phytopharmaceuticals from the Amazonian Plant Libidibia ferrea for Wound Healing in Dogs. Front. Vet. Sci. 2020, 7, 244. [CrossRef]

17. Calixto, J.B.; Scheidt, C.; Otuki, M.; Santos, A.R.S. Biological activity of plant extracts: Novel analgesic drugs. Expert Opin. Emerg. Drugs 2001, 6, 261-279. [CrossRef] [PubMed] 
18. Macêdo, D.G.; Ribeiro, D.A.; Coutinho, H.D.M.; Menezes, I.R.A.; Souza, M.M.A. Práticas terapêuticas tradicionais: Uso e conhecimento de plantas do cerrado no estado de Pernambuco (Nordeste do Brasil). Bol. Latinoam. Caribe Plantas Med. Aromat. 2015, 14, 491-508.

19. Cimanga, R.K.; Nsaka, S.L.; Tshodi, M.E.; Mbamu, B.M.; Kikweta, C.M.; Makila, F.B.M.; Cos, P.; Maes, L.; Vlietinck, A.J.; Exarchou, V.; et al. In vitro and in vivo antiplasmodial activity of extracts and isolated constituents of Alstonia congensis root bark. J. Ethnopharmacol. 2019, 242, 111736. [CrossRef]

20. Zoghbi, M.D.G.B.; Andrade, E.H.A.; Carreira, L.M.M.; Rocha, E.A.S. Comparison of the main components of the essential oils of "priprioca": Cyperus articulatus var. Articulatus, L., C. Articulatus var. Nodosus, L., C. Prolixus kunth and C. Rotundus, L. J. Essent. Oil Res. 2008, 20, 42-45. [CrossRef]

21. Ngo Bum, E.; Schmutz, M.; Meyer, C.; Rakotonirina, A.; Bopelet, M.; Portet, C.; Jeker, A.; Rakotonirina, S.V.; Olpe, H.R.; Herrling, P. Anticonvulsant properties of the methanolic extract of Cyperus articulatus (Cyperaceae). J. Ethnopharmacol. 2001, 76, 145-150.

22. Ahmad, A.; Khan, A.; Manzoor, N.; Khan, L.A. Evolution of ergosterol biosynthesis inhibitors as fungicidal against Candida. Microb. Pathog. 2010, 48, 35-41. [CrossRef] [PubMed]

23. Hilário, F.F.; de Paula, R.C.; Silveira, M.L.T.; Viana, G.H.R.; Alves, R.B.; Pereira, J.R.C.S.; Silva, L.M.; de Freitas, R.P.; de Pilla Varotti, F. Synthesis and Evaluation of Antimalarial Activity of Oxygenated 3-alkylpyridine Marine Alkaloid Analogues. Chem. Biol. Drug Des. 2011, 78, 477-482. [CrossRef] [PubMed]

24. Bénard, J.; Douc-Rasy, S.; Ahomadegbe, J.C. TP53 family members and human cancers. Hum. Mutat. 2003, 21, 182-191. [CrossRef] [PubMed]

25. Rukunga, G.M.; Muregi, F.W.; Omar, S.A.; Gathirwa, J.W.; Muthaura, C.N.; Peter, M.G.; Heydenreich, M.; Mungai, G.M. Anti-plasmodial activity of the extracts and two sesquiterpenes from Cyperus articulatus. Fitoterapia 2008, 79, 188-190. [CrossRef]

26. Weniger, H. Review of Side Effects and Toxicity of Chloroquine; World Health Organization: Geneva, Switzerland, 1979.

27. Chatre, C.; Roubille, F.; Vernhet, H.; Jorgensen, C.; Pers, Y.M. Cardiac Complications Attributed to Chloroquine and Hydroxychloroquine: A Systematic Review of the Literature. Drug Saf. 2018, 41, 919-931. [CrossRef]

28. Tsai, Y.C.; Hsu, H.C.; Yang, W.C.; Tsai, W.J.; Chen, C.C.; Watanabe, T. $\alpha$-Bulnesene, a PAF inhibitor isolated from the essential oil of Pogostemon cablin. Fitoterapia 2007, 78, 7-11. [CrossRef]

29. Erhirhie, E.O.; Ihekwereme, C.P.; Ilodigwe, E.E. Advances in acute toxicity testing: Strengths, weaknesses and regulatory acceptance. Interdiscip. Toxicol. 2018, 11, 5-12. [CrossRef]

30. Costa, E.S.S.; Dolabela, M.F.; Póvoa, M.M.; Oliveira, D.J.; Müller, A.H. Estudos farmacognósticos, fitoquímicos, atividade antiplasmódica e toxicidade em Artemia salina de extrato etanólico de folhas de Montrichardia linifera (Arruda) Schott, Araceae. Braz. J. Pharmacogn. 2009, 19, 834-838. [CrossRef]

31. Mojarrab, M.; Emami, S.A.; Gheibi, S.; Taleb, A.M.; Heshmati Afshar, F. Evaluation of anti-malarial activity of Artemisia turcomanica and A. kopetdaghensis by cell-free $\beta$-hematin formation assay. Res. J. Pharmacogn. 2016, 3, 59-65.

32. Metuge, J.A.; Nyongbela, K.D.; Mbah, J.A.; Samje, M.; Fotso, G.; Babiaka, S.B.; Cho-Ngwa, F. Anti-Onchocerca activity and phytochemical analysis of an essential oil from Cyperus articulatus L. BMC Complement. Altern. Med. 2014, 14, 223. [CrossRef]

33. Silva, N.C.d.; Gonçalves, S.F.; de Araújo, L.S.; Kasper, A.A.M.; da Fonseca, A.L.; Sartoratto, A.; Castro, K.C.F.; Moraes, T.M.P.; Baratto, L.C.; de Varotti, F.P.; et al. In vitro and in vivo antimalarial activity of the volatile oil of Cyperus articulatus (Cyperaceae). Acta Amaz. 2019, 49, 334-342. [CrossRef]

34. Dolabela, M.F.; Da Silva, A.R.P.; Ohashi, L.H.; Bastos, M.L.C.; Da Silva, M.C.M.; Vale, V.V. Estudo in silico das atividades de triterpenos e iridoides isolados de Himatanthus articulatus (Vahl) Woodson. Rev. Fitos 2018, 12, 227. [CrossRef]

Publisher's Note: MDPI stays neutral with regard to jurisdictional claims in published maps and institutional affiliations. 